\title{
The Two Noble Kinsmen: Internal and Legal Transparency in the WTO and Their ConNection to Preferential and Regional Trade Agreements
}

\section{Maria Panezi* \\ Center for International Governance Innovation, ON Canada}

\begin{abstract}
The proliferation of Preferential Trade Agreements (PTAs) andRegional Trade Agreements (RTAs) has given rise to significant debate on the need to measure, understand and possibly regulate the impact these agreements have on the multilateral trading system under the umbrella of the World Trade Organization (WTO). This article will discuss the two Doha Transparency Mechanisms (legal transparency) regarding regional trade agreements, as they appear in two General Council decisions from 2006 and 2010. I will argue based on a closer look and a consistent interpretation of Paragraph 10 of the Doha Ministerial Declaration that there is another type of transparency that is relevant to the discussion on PTAs/RTAs, namely "internal transparency." "Internal transparency stricto sensu" highlights the significance of trust in the WTO institutional processes, such as negotiations, decision-making, dispute settlement and trade monitoring that the representatives of developing member states should have in order for the WTO system to function productively. "Internal transparency lato sensu" is introduced in this article as an extension to include any decision-making deficits, exclusionary and asymmetrical outcomes specifically in the area of unchecked Preferential Trade Agreement proliferation. Instead of a conclusion, the article offers some proposals for more a meaningful progress in the WTO with respect to PTAs/RTAs The proposals aim at raising the profile of both legal and internal of transparency and posit that raising the profile of one will inevitably lead in improvements in the other.
\end{abstract}

\section{CONTENTS}

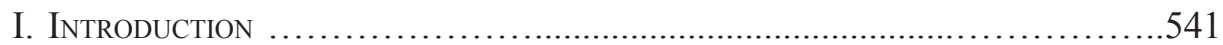

II. The Legal Framework for PTAs/RTAs .............................................543

III. The Doha Transparency Mechanisms .............................................549

* Post Doctoral Fellow, The Center for International Governance Innovation, Waterloo, ON. LL.B. (2005), Athens University, Greece, LL.M. (2006) NYU, Ph.D. (2015) Osgoode; She can be reached at mpanezi@cigionline.org. The author would like to thank Peer Zumbansen, Federico Ortino, Daniel Drache, Robert Wai, Achilles Skordas, Argyri Panezi and the speakers and participants of the Panel entitled "Transparency and the proliferation of Regional Trade Agreements: how to ensure developing country market access when the spaghetti bowl keeps getting bigger?" at the 2016 WTO Public Forum for various discussions, comments and suggestions. The usual disclaimer applies. 
IV. Asymmetrical Aspects of PTAs/RTAs ........................................553

V. PTAs/RTAs and Trade Liberalization ......................................556

VI. The Sutherland Report on PTAs/RTAs and Development .............559

VII. EXPANDING the Notion of Internal TranSPAREnCy..........................563

VIII. The renewed Nairobi Transparency Commitment.........................565

IX. Mutual Transparency Spillovers: Three Proposals in Lieu of a

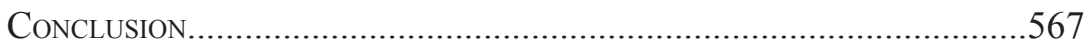




\section{INTRODUCTION}

The proliferation of Preferential Trade Agreements (PTAs) and Regional Trade Agreements (RTAs) ${ }^{1}$ has given rise to significant debate on the need to measure, understand and possibly regulate the impact these agreements have on the multilateral trading system under the umbrella of the World Trade Organization (WTO). ${ }^{2}$ PTAs and RTAs were not only understood as a possibility in the world trading system, they were also formally allowed by the WTO Agreements. However, as the numbers of PTAs/RTAs were rising, concerns started being raised in the WTO: should these agreements be monitored? The answer was yes. Reporting mechanisms were created and more discussions followed on the compatibility of these agreements to the WTO ones, as well as their economic and political impact on the world trading system.

After the Seattle failure and the inability to conclude the Doha Round the issue of PTAs/RTAs has acquired new dimensions. As WTO members were unable to reach agreements under the auspices of the organization, they resorted to trade deals outside, with other like-minded parties. In the last decade, news on world trade has been dominated by the discussions on Mega-Regionals, and the WTO no longer is as newsworthy. The Transatlantic Trade and Investment Partnership (TTIP), the Trans-Pacific Partnership (TPP) and the European Union (EU)-Canada Comprehensive Economic Trade Agreement (CETA) have been, for better and for worse, in the front page of major world newspapers, while the recent WTO Ministerial in Nairobi barely made it to any newspapers at all.

In the WTO, transparency mechanisms were created in order to keep a formal list of signed PTAs/RTAs. This paper will examine first this version of formal or legal transparency linked to regionalism. Second, I will argue that there is another

\footnotetext{
For definitions see next section. In this article all non-WTO trade agreements will be referred to as Preferential Trade Agreements and Regional Trade Agreements and occasionally as Free Trade Agreements. The exact differences between the three will be briefly addressed in the next section. This article will also use the term "Preferential Trade Agreements" instead of "Preferential Trade Arrangements". The GATT uses the term "arrangements", however, I argue that the two terms can be used in this context interchangeably.

2 See, among many, Jo-Ann Crawford \& Roberto V. Fiorentino, The Changing Landscape of Regional Trade Agreements, World Trade Organization paper (2005), available at https://www.wto.int/english/res_e/booksp_e/discussion_papers8_e.pdf; Martin Roy etal, Services Liberalization in the NewGeneration of Preferential Trade Agreements (PTAs): How Much Further than the GATS? 6 World Trade Rev. 155-92 (2007); and more recently Sébastien Miroudot \& Ben Shepherd, The Paradox of 'Preferences': Regional Trade Agreements and Trade Costs in Services 37 The World ECONOMy 1751-72 (2014); Bilateral and regional trade agreements: Commentary and analysis, Vol. 1 (Simon Lester et al. eds., 2015); Denis Medvedev, Beyond Trade: The Impact of Preferential Trade Agreements on FDI Inflows, 40:1 World Development 49-61 (2012); Joost Pauwelyn \& Wolfgang Alschner, Forget About the WTO: The Network of Relations Between Preferential Trade Agreements (PTAs) and 'Double PTAs' (2014), available at SSRN http://ssrn.com/abstract=2391124 (last visited Jun. 10, 2016); Chad Bown et al., What Do We Know About Preferential Trade Agreements and Temporary Trade Barriers?, in Trade Cooperation: The Purpose, Design and Effects of Preferential Trade Agreements 433-62 (A. Dür \& M. Elsig eds., 2015).
} 
type of transparency that is relevant to the discussion on PTAs/RTAs, namely "internal transparency." In this analysis I will also identify deficits in the two transparencies. Finally, I will conclude with some proposals to raise the profile of both forms of transparency and posit that raising the profile of one will inevitably lead in improvements in the other. The two notions are complementary and can work together, just like John Fletcher and William Shakespeare collaborating in writing the play "The Two Noble Kinsmen." 3 In other words, if marginalized countries are more meaningfully integrated in the WTO, PTAs and RTAs will not be as impactful on their position in the global economy. Or, if the WTO established transparency mechanisms function optimally, this will lead to bringing small and medium economies out of the sidelines and help their participation in world trade.

The article will proceed as follows: First, I will briefly discuss the existing legal framework for PTAs and RTAs in the WTO context. This includes both provisions in the WTO Agreements as well as the (limited) jurisprudence from the dispute settlement process. In the second part I will describe the two Doha Transparency Mechanisms regarding regional trade agreements, as they appear in two General Council decisions from 2006 and 2010. ${ }^{4}$ The article will then move to explore the asymmetrical elements that PTAs and RTAs introduce in the world trading system in Part III, and the potential clash with trade liberalization in Part VI. Part V will move to elaborate on how the Sutherland Report, which is to date the most comprehensive WTO self-assessment document, failed to capture any criticism for their proliferation and their impact on the organization. Part VI moves beyond the criticism on the failure of the Sutherland Report to address the trade liberalization problems and asymmetrical elements for developing countries that RTAs and PTAs inherently produce. It further argues that based on a closer look and a consistent interpretation of Paragraph 10 of the Doha Ministerial Declaration ${ }^{5}$, the proliferation of PTAs and RTAs should have been flagged in the WTO as another facet of the internal transparency problems of the WTO. Part VII returns to the Doha transparency mechanisms and discusses how the December 2015 Nairobi Ministerial Declaration ${ }^{6}$ pushes forward the notion that concrete action must be taken on PTA/RTA monitoring. Finally, instead of a conclusion, the article offers some proposals for more a meaningful progress in the WTO with respect to PTAs/ RTAs. A combination of both a firm and a flexible stance is necessary to address this expanding phenomenon in international trade regulation.

3 John Fletcher \& William Shakespeare, Two Noble Kinsmen, (E. M. Waith ed., Oxford English Texts Series, Oxford University Press, 1998) (1634). For the controversy regarding the paternity of the text see the introduction by E.M. Waith and also for distinguishing parts written by each author Gerard Ledger \& Thomas Merriam, Shakespeare, Fletcher, and the Two Noble Kinsmen, 9 Literary \& Linguistic Computing 235-48 (1994). For a long time, there was controversy over the attribution of the text to each of the authors.

4 Transparency Mechanism for Regional Trade Agreements, General Council Decision of 14 December 2006, WT/L/671 (Dec. 18, 2006) and Transparency Mechanism for Preferential Trade Agreements, General Council Decision of 14 December 2010, WT/L 862010 (Dec. 16, 2010).

5 World Trade Organization, Doha Ministerial Declaration, WT/MIN(01)/DEC/1 (Nov. 20, 2001), 41 I.L.M. 746 (2002), para. 10 [hereinafter Doha Declaration].

6 World Trade Organization, Nairobi Ministerial Declaration, WT/MIN(15)/DEC/1 (Dec. 19, 2015). 
One clarification is necessary here regarding the transparency terminology used in this article. When referring to "internal transparency", the article, drawing from Article 10 of the Doha Ministerial Declaration first refers to "internal transparency stricto sensu" to decision-making deficits of developing countries in the WTO. It highlights the significance of trust in the WTO institutional processes, such as negotiations, decision-making, dispute settlement and trade monitoring that the representatives of member states should have in order for the WTO system to function productively. ${ }^{7}$ However, as I argue in Part VI, this notion should be expanded to include other phenomena with the same effect in the WTO. This, which can be called "internal transparency lato sensu"s is introduced as an extension of decision-making deficits. Power imbalances in the WTO that have led to developing countries' exclusion have also created other asymmetrical outcomes, specifically in the area of Preferential Trade Agreement proliferation. Finally, the mechanisms introducing an obligation of WTO member states to report information within the organization, to publish their trade-related legislation, disclose the PTAs and RTAs they enter into with others, and other rule of law obligations that exist in order to benefit other member states' their traders and consumers can be called "Legal Transparency." The two transparencies intersect, and as I will propose in the concluding section, improving the one will help improve the other.

\section{The LegAL Framework For PTAs/RTAs}

The exception of PTAs/RTAs is considered the most important exception to the Most Favored Nation (MFN) principle. ${ }^{9}$ The basic PTA rules are XXIV of the General Agreement on Tariffs and Trade (GATT) under the title "Territorial Application - Frontier Traffic - Customs Unions and Free-Trade Areas”, together with the Understanding on the Interpretation of Article XXIV of the GATT 1994, ${ }^{10}$ Article V of the General Agreement on Trade in Services (GATS) and the Enabling Clause. These provisions introduce five types of Preferential or Regional Trade Agreements, included in the WTO Agreements ${ }^{11}$ and deemed to generally be WTOcompatible.

During the initial negotiation of the GATT, in the 40s, there was discussion to preserve only those preferential schemes that were long-standing, but this

Doha Declaration, supra note 5, para. 10 (internal transparency definition and commitment).

8 I use the term "transparency stricto sensu" to distinguish it from the extension of transparency which I will be proposing, which I call "transparency lato sensu".

9 Michael J. Trebilcock,. \& Robert Howse. The Regulation of International Trade 193 (3d ed. 2005).

10 General Agreement on Tariffs and Trade 1994, Apr. 15, 1994, Marrakesh Agreement Establishing the World Trade Organization, Annex 1A, The Legal Texts: The Results of the Uruguay Round of Multilateral Trade Negotiations 17 (1999), 1867 U.N.T.S. 187, 33 I.L.M. 1153 (1994).

11 Final Act Embodying the Results of the Uruguay Round of Multilateral Trade Negotiations, Apr. 15, 1994, The Legal Texts: The Results of the Uruguay Round of Multilateral Trade Negotiations 2 (1999), 1867 U.N.T.S. 14, 33 I.L.M. 1143 (1994). 
suggestion did not prevail. ${ }^{12}$ The so-called London Draft discussed the inclusion of existing and future Custom Unions within the GATT 1994. ${ }^{13}$ The notion of Free Trade Agreements (FTAs) was added later on. ${ }^{14}$ Mavroidis et al. reject the claim that this inclusion was put forward in order to accommodate the subsequent creation of the European Communities. ${ }^{15}$ Preferential trade exceptions were negotiated to some extent, and resulted to a relaxed scheme, which is based on three obligations: to notify, to liberalize among members to the Regional Trade Agreement or the Customs Union (internal requirement) and not to raise protectionism towards nonmembers (external requirement). ${ }^{16}$

An interpretation consistent with the principle of pacta sunt servanta evidently favors any agreement the Contracting Parties made. Even if RTAs are not encouraged in the WTO, at least they are tolerated. Article XXIV paragraph 4 discusses the overall framework for such RTAs:

The contracting parties recognize the desirability of increasing freedom of trade by the development, through voluntary agreements of closer integration between the economies of the countries parties to such agreements. They also recognize that the purpose of a customs union or of a free trade area should be to facilitate trade between the constituent territories and not to raise barriers to the trade of other contracting parties with such territories.

Paragraph 5 explicitly proclaims that:

... the provisions of this Agreement shall not prevent, as between the territories of contracting parties, the formation of a customs union or of a free-trade area or the adoption of an interim agreement necessary for the formation of a customs union or of a free-trade area.

Customs Unions are described in Paragraph 8 (a) of Article XXIV as follows:

For the purposes of this Agreement: A customs union shall be understood to mean the substitution of a single customs territory for two or more customs territories so that

(i) duties and other restrictive regulations of commerce (...) are eliminated with respect to substantially all trade between the constituent territories of the union or at least with respect to substantially all the trade in products originating in such territories, and,

(ii) ... substantially the same duties and other regulations of commerce are applied by each of the members of the union to the trade territories not included in the union.

Douglas Irwin et aL., The Genesis of the GATT 109 (2008).

Id.

Id. at 122 .

Id. at $167-68$.

16 Mitsu Matsushita et al., The World Trade Organization, Law, Practice and Policy 555 (2006). 
Paragraph 5 (a) of Article XXIV limits Customs Unions by explaining that:

with respect to a customs union ... the duties and other regulations of commerce imposed at the institution of any such union ... in respect of trade with contracting parties not parties to such union ... shall not on the whole be higher or more restrictive than the general incidence of the duties and regulations of commerce applicable in the constituent territories prior to the formation of such union ... ${ }^{17}$

Similarly, second category of RTAs, Free Trade Areas, are regulated in the same Paragraph 8 of Article XXIV, under (b):

A free-trade area shall be understood to mean a group of two or more customs territories in which the duties and other restrictive regulations of commerce ... are eliminated on substantially all the trade between the constituent territories in products originating in such territories.

Article XXIV 5 (b) also restricts the scope of Free Trade Areas:

with respect to a free trade area ... the duties and other regulations of commerce maintained in each of the constituent territories and applicable at the formation of such free-trade area ... to the trade of contracting parties not included in such area ... shall not be higher or more restrictive than the corresponding duties and other regulations of commerce existing in the same constituent territories prior to the formation of the free-trade area ...

Free Trade Areas and Customs Unions essentially overlap since their members have to liberalize trade among them. The difference between the two is that a Customs Union additionally establishes a common external commercial policy. ${ }^{18}$ Also with respect to Customs Unions the effect in trade restriction is examined overall, unlike Free Trade Areas where individual instruments are investigated.

The third- hybrid- category, discussed in Article 5 under both (a) and (b) comprises the interim agreements necessary for the formation of a Customs Union or a Free Trade Area. Such interim agreements must be concluded within a "reasonable length of time" according to Paragraph 5 (c) of Article XXIV. According to the Understanding on Article XXIV, a reasonable length of time does not exceed the duration of ten years. ${ }^{19}$

Very important in terms of setting the foundations for transparency in this context is paragraph 7 of Article XXIV which reads as follows:

(a) Any contracting party deciding to enter into a customs union or free-trade area, or an interim agreement leading to the formation of such a union

17 Emphasis added.

18 See on this matter of distinguishing between the two, Anne O. Krueger, Free Trade Agreements Versus Customs Unions 54 J. Dev. Econ. 169-87 (1997).

19 Understanding on the Interpretation of Article XXIV of the General Agreement on Tariffs and Trade 1994 para. 3, The Legal Texts: The Results of the Uruguay Round of Multilateral Trade Negotiations 2 (1999), 1867 U.N.T.S. 14, 33 I.L.M. 1143 (1994). 
or area, shall promptly notify the CONTRACTING PARTIES and shall make available to them such information regarding the proposed union or area as will enable them to make such reports and recommendations to contracting parties as they may deem appropriate.

(b) If, after having studied the plan and schedule included in an interim agreement referred to in paragraph 5 in consultation with the parties to that agreement and taking due account of the information made available in accordance with the provisions of subparagraph (a), the CONTRACTING PARTIES find that such agreement is not likely to result in the formation of a customs union or a free-trade area within the period contemplated by the parties to the agreement or that such period is not a reasonable one, the CONTRACTING PARTIES shall make recommendations to the parties to the agreement. The parties shall not maintain or put into force, as the case may be, such agreement if they are not prepared to modify in accordance with these recommendations.

(c) Any substantial change in the plan or schedule referred to in paragraph 5 (c) shall be communicated to the CONTRACTING PARTIES which may request the contracting parties concerned to consult with them if the change seems likely to jeopardize or delay unduly the formation of the customs union or of the free-trade area.

The fourth type of such agreements appears in Paragraph 2 (c) of the Enabling Clause that is now part of the GATT. The Enabling Clause establishes a PTA. According to paragraph 2 (c) the differential and more favourable treatment of Paragraph 1 applies also to:

Regional or global arrangements entered into amongst less-developed contracting parties for the mutual reduction or elimination of tariffs and, in accordance with criteria or conditions which may be prescribe by the CONTRACTING PARTIES, for the mutual reduction or elimination of nontariff measures, on products imported from one another.

The fifth is Economic Integration Agreements under Article V of the GATS (entitled "Economic Integration"), according to which:

This Agreement shall not prevent any of its Members from being a party to or entering into an agreement liberalizing trade in services between or among the parties to such an agreement, provided that such an agreement:

(a) has substantial sectoral coverage, and

(b) provides for the absence or elimination of substantially all discrimination, in the sense of Article XVII, between or among the parties, in the sectors covered under subparagraph (a), through,

(i) elimination of existing discriminatory measures, and/or

(ii) prohibition of new or more discriminatory measures,

either at the entry into force of that agreement or on the basis of a reasonable time-frame ...

Article V paragraph 5 of the GATS further requires an advanced notice period of at least 90-days. Article V bis of the GATS discusses labor market integration 
agreements, also notified, just like Agreements of Article V GATS to the Council for Trade in Services. Arguably, Article V is stricter than Article XXIV, since the former discusses "substantial sectoral coverage", including trade volume and modes of supply ${ }^{20}$ while the latter extends to "substantially all trade."

To date, 258 Regional Trade Agreements and 26 Preferential Trade Agreements have been notified under the GATT/WTO system and are in force either between countries (the majority), ${ }^{21}$ or between countries and existing PTAs and Customs Unions. ${ }^{22}$ Very few cases have been brought before the Dispute Settlement Body with respect to PTAs and RTAs. The limited amount of jurisprudence is considered not surprising, ${ }^{23}$ especially in view of the complex landscape these agreements create and the content of Article XXIV and others. The original burden of proof for a complaint relating to article XXIV and its equivalents is easy to meet; all RTAs and PTAs are deviations from the Most Favored Nation rule by definition. As the burden of proof shifts to the defendant, it is up to them to demonstrate that the PTA or RTA is compatible with their GATT obligations. The lack of adequate monitoring mechanisms also contributes to this confusion and reluctance to litigate.

The cases that brought the issue of RTAs and PTAs to be examined before the Dispute Settlement Body are Turkey - Textiles ${ }^{24}$ and Argentina - Footwear (EC) ${ }^{25}$ mainly, but also, Canada Autos, ${ }^{26}$ Brazil - Tyres ${ }^{27}$ and U.S. - Steel Safeguards. ${ }^{28}$

20 See David A. Gantz, Liberalizing International Trade after Doha: Multilateral, Plurilateral, Regional, and Unilateral Initiatives 138 (2013).

21 Viet D. Do \& William Watson, Economic Analysis of Regional Trade Agreements 7-22 at 8 (2006).

22 The World Bank has created a comprehensive database to assemble data for FTAs notified before the WTO and those that have not been notified yet. See Global Preferential Trade Agreement Database available at http://wits.worldbank.org/gptad/library.aspx (last visited Jun. 10, 2016).

23 Matsushita et Al., supra note 16 at 582-89, see also Petros Mavroidis, If I Don't Do It Somebody Else Will (Or Won't), Mimeo (2005).

24 Appellate Body Report, Turkey - Restrictions on Imports of Textile and Clothing Products, WT/DS34/AB/R (Oct. 22, 1999); Panel Report, Turkey - Restrictions on Imports of Textile and Clothing Products, WT/DS34/R (May 31, 1999) (adopted Nov. 19, 1999 as modified by Appellate Body Report, Turkey - Restrictions on Imports of Textiles and Clothing Products WT/DS34/AB/R (Oct. 22, 1999))

25 Appellate Body Report, Argentina - Safeguard Measures on Imports of Footwear, WT/ DS121/AB/R (Dec. 14, 1999); Panel Report, Argentina - Safeguard Measures on Imports of Footwear, WT/DS121/R (June 25, 1999) (adopted Jan. 12, 2000 as modified by Appellate Body Report, Argentina - Safeguard Measures on Imports of Footwear, WT/ DS121/AB/R (Dec. 14. 1999)).

26 Appellate Body Report, Canada - Certain Measures Affecting the Automotive Industry, WT/DS139/AB/R, WT/DS142/AB/R (May 31, 2000); Panel Report, Canada - Certain Measures Affecting the Automotive Industry, WT/DS139/R, WT/DS142/R (Feb. 11, 2000) (adopted June 19, 2000 as modified by Appellate Body Report, Canada-Certain Measures Affecting the Automotive Industry, WT/DS139/AB/R, WT/DS142/AB/R (May 31, 2000)).

27 Appellate Body Report, Brazil - Measures Affecting Imports of Retreaded Tyres, WT/ DS332/AB/R, (Dec. 3, 2007); Panel Report, Brazil - Measures Affecting Imports of Retreaded Tyres, WT/DS332/R (Jun. 12, 2007) (adopted Dec. 17, 2007 as modified by Appellate Body Report, Brazil - Measures Affecting Imports of Retreaded Tyres, WT/ DS332/AB/R (Dec. 3, 2007)).

28 Appellate Body Report, United States - Definitive Safeguard Measures on Imports of Certain Steel Products, WT/DS248/AB/R, WT/DS249/AB/R, WT/DS251/AB/R, WT/ 
Turkey - Textiles focused on Customs Unions and the Appellate Body ruled that a Customs Union may be inconsistent with the GATT, and in Argentina - Footwear, the Panel discussed some GATT-consistency aspects of the Southern Common Market (MERCOSUR) ${ }^{29}$ A test for RTAs and PTAs under the GATT has three components: first, a procedural requirement (the notification), second, a substantive internal requirement, the obligation to liberalize all trade amongst PTA/RTA members, and third, a substantive external requirement, the obligation not to raise the overall level of protection. ${ }^{30}$

In a recent case between Peru and Guatemala, the Panel and the Appellate Body members were asked to determine the relevance of a Free Trade Agreement between the two countries signed in $2011^{31}$ to the WTO Agreements. In particular, Peru argued that it had a right based on the FTA and upon agreement with Guatemala to maintain the price range system on certain agricultural products under scrutiny in this case. ${ }^{32}$ Peru asserted that under WTO law the price range system would be illegal, but this is not the case as it is consistent with the FTA and the FTA prevails. ${ }^{33}$ Guatemala on the other hand argued that the WTO Panel cannot discuss the FTA as it is not related to the WTO covered agreement. ${ }^{34}$ The Panel discussed the chronology of the negotiations and the entry into force of the Peru, Costa Rica, Honduras, Panama and Guatemala FTA. ${ }^{35}$ The Panel continued with a limited but substantive analysis, ${ }^{36}$ but concluded that since the FTA has not entered into force, it was not necessary for the Panel to rule on the content of the FTA and its relationship to the WTO covered Agreements. ${ }^{37}$

This dictum implies that if the FTA had been in force, the Panel would have answered the question of the relationship between the FTA and the WTO Agreements (the GATT and the Agreement on Agriculture). ${ }^{38}$ The Appellate Body

DS252/AB/R, WT/DS253/AB/R, WT/DS254/AB/R，WT/DS258/AB/R，WT/DS259/ AB/R (Nov. 10, 2003); Panel Report, United States - Definitive Safeguard Measures on Imports of Certain Steel Products, WT/DS248/R, WT/DS249/R, WT/DS251/R, WT/ DS252/R, WT/DS253/R, WT/DS254/R, WT/DS258/R, WT/DS259/R, and Corr.1 (Jul. 11, 2003) (adopted Dec. 10, 2003 as modified by Appellate Body Report, United States Definitive Safeguard Measures on Imports of Certain Steel Products, WT/DS248/AB/R, WT/DS249/AB/R，WT/DS251/AB/R，WT/DS252/AB/R，WT/DS253/AB/R，WT/ DS254/AB/R, WT/DS258/AB/R, WT/DS259/AB/R (Nov. 10, 2003)).

29 Also Peter Van den Bossche, The LaW and Policy of the World Trade Organization: Text, Cases and Materials at 699 (2008).

30 Matsushita ET AL., supra note 16, at 555.

31 Tratado de Libre Comercio Guatemala-Perú signed between Guatemala and Peru in December 2011, avalilable at $\mathrm{http} / / / \mathrm{www}$.sice.oas.org/Trade/GTM_PER_FTA_s/GTM_ PER_ToC_s.asp (last visited Jun. 10, 2016).

32 Panel Report, Peru - Additional Duty on Imports of Certain Agricultural Products, 1 7.24, WT/DS457/R, WT/DS457/R/Add.1 (Nov. 27, 2015) (adopted Jul. 31, 2015 as modified by Appellate Body Report, Peru - Additional Duty on Imports of Certain Agricultural Products, WT/DS457/AB/R (July 20, 2015)).

Id. 97.25 .

Id. $₫ 7.27$.

Id. ๆ 7 7.30-7.33.

Id. $₫$ ๆ 7.34-7.42, esp. 7.40 seq.

Id. $\uparrow$ 8.1.f.

38 See Stephanie Hartmann, Recognizing the Limitations of WTO Dispute Settlement - The Peru-Price Bands Dispute and Sources of Authority for Applying Non-WTO Law in 
further affirmed this finding, saying first that the FTA was not relevant in the interpretation of the Agreement on Agriculture ${ }^{39}$ and second that the Panel "did not err in declining to make findings as to whether the FTA modified the WTO rights and obligations between Peru and Guatemala." ${ }^{40}$ In one sense, the decisions show that the Panels and the Appellate Body, if relevant, are willing to go into depth in discussing PTAs/RTAs and FTAs. However, the courts carefully avoided actually engaging in the controversial questions that such cases raise.

\section{The Doha Transparency Mechanisms}

The Doha Round has been known, among other things, for not having produced any agreements in almost over a decade since its launch. ${ }^{41}$ However, the General Council adopted two decisions, one in 2006 and one in 2010, establishing two transparency mechanisms, one for Preferential Trade Agreements and one for Regional Trade Agreements. Arguably, both mechanisms address issues covered in the Doha agenda. More specifically, the preamble of the Doha Ministerial Declaration emphasizes the compatibility of Regional Trade Agreements and the WTO:

We stress our commitment to the WTO as the unique forum for global trade rule-making and liberalization, while also recognizing that regional trade agreements can play an important role in promoting the liberalization and expansion of trade and in fostering development. ${ }^{42}$

Within this framework, paragraph 29 of the Doha Declaration further provides that:

We also agree to negotiations aimed at clarifying and improving disciplines and procedures under the existing WTO provisions applying to regional

WTO Disputes 48 Geo. WASH. InT'L L. Rev 617-79 (2016), Joost Pauwelyn, Interplay between the WTO Treaty and Other International Legal Instruments and Tribunals: Evolution after 20 Years of WTO Jurisprudence (2016), available at SSRN http://ssrn. com/abstract=2731144 (last visited Jun. 10, 2016).

39 Appellate Body Report, Peru - Additional Duty on Imports of Certain Agricultural Products, ๆ 6.4.c, WT/DS457/AB/R, WT/DS457/AB/R/Add.1 (Jul. 20, 2015) (adopted Jul. $31,2015)$.

$40 \quad I d .96 .5$.

41 See at the WTO website Beginda Pakpahan, Deadlock in the WTO: What Is Next?, available at https://www.wto.org/english/forums_e/public_forum12_e/art_pf12_e/ art19.htm (last visited Jun. 10, 2016) and also among many on this topic James Scott \& Sophie Harman, Beyond Trips: Why the WTO's Doha Round Is Unhealthy, 34 THIRD WorLd Q. 1361-76 (2013); Bernard Hoekman \& Petros Mavroidis, WTO 'à la Carte'or 'Menu du Jour'? Assessing the Case for More Plurilateral Agreements, 26 Eur. J. INT'L L. 319-43 (2015); Stephen Woolcock, Getting past the WTO Deadlock: The Plurilateral Option? (2013), available at http://eprints.lse.ac.uk/55842 (last visited Jun. 10, 2016)/; Erik Dickinson, The Doha Development Dysfunction: Problems of the WTO Multilateral Trading System, 3 The Global Bus. L. Rev. 6 (2013).

42 Doha Declaration, supra note 5, para. 4, preamble. 
trade agreements. The negotiations shall take into account the developmental aspects of regional trade agreements. ${ }^{43}$

As such, with the increasing number of Regional Trade Agreements being signed by WTO member states, the regulatory turn on "procedures applying to existing WTO provisions" focused on the lack of a functioning multilateral surveillance mechanism for RTAs. ${ }^{44}$ Thus, the Negotiating Group on Rules focused on transparency since October $2002^{45}$ and in 2006 the General Council adopted the first decision on transparency entitled "Transparency Mechanism for Regional Trade Agreements" (RTA/2006 Decision). ${ }^{46}$ In 2010, the General Council adopted the second decision, entitled "Transparency Mechanism for Preferential Trade Agreements" (PTA/2010 Decision). ${ }^{47}$ Both decisions can be immediately implemented on a provisional basis, as is explained in paragraph 47 of the Doha Declaration,,$^{48}$ even though the Doha Round is treating all negotiations as a single undertaking. The scope of the two instruments differs in that the first discusses any sub-multilateral trade agreements among WTO member states, while the second discusses any non-reciprocal preferential treatment measures adopted on behalf of more developed countries in order to assist less and least-developed WTO member states.

The most important contributions of the new RTA mechanism to the existing system provided in Article XXIV of the GATT are the early notification mechanism and the procedures for consideration and publication of RTAs. The PTA mechanism also establishes a similar consideration and publication mechanism, although slightly less stringent with respect to the process and the time-frames involved.

The early notification mechanism introduced in the RTA/2006 Decision in part A paragraph 1 provides that:

(a) Members participating in new negotiations aimed at the conclusion of an RTA shall endeavour to so inform the WTO.

(b) Members parties to a newly signed RTA shall convey to the WTO, in so far as and when it is publicly available, information on the RTA, including its official name, scope and date of signature, any foreseen timetable for its entry into force or provisional application, relevant contact points and/ or website addresses, and any other relevant unrestricted information.

2. The information referred to in paragraph 1 above is to be forwarded to the WTO Secretariat, which will post it on the WTO website and will periodically provide Members with a synopsis of the communications received.

Paragraph 3 of Part B in the RTA/2006 decision clarifies the prompt notification period discussed in Paragraph 7 of Article XXIV GATT, defining it as "no later

$43 \quad I d$. para. 29.

44 See Roberto V. Fiorentino et al., The Landscape of Regional Trade Agreements and WTO Surveillance, in Multilateralizing Regionalism: Challenges for the Global Trading System 56 (Patrick Low \& Richard Baldwin eds., 2009).

$45 \quad I d$. at 57.

46 Transparency Mechanism for Regional Trade Agreements, General Council Decision of 14 December 2006, WT/L/671, Dec. 18, 2006.

47 Transparency Mechanism for Preferential Trade Agreements, General Council Decision of 14 December 2010, WT/L 86 2010, Dec. 16, 2010.

48 Doha Declaration, supra note 5, para. 48. 
than directly following the parties' ratification of the RTA or any party's decision on application of the relevant parts of an agreement, and before the application of preferential treatment between the parties." Paragraph 4 requires that the full text of the RTAs is notified to the WTO.

The mechanism described in the RTA/2006 Decision under "Procedures to Enhance Transparency" applies to both RTAs and PTAs, but with respect to PTAs it is further elaborated on in the PTA/2010 Decision. In particular, the RTA/2006 Decision provides that after notification, RTAs are considered by Member states within the year of the date of notification. The WTO Secretariat also prepares a factual presentation in which it "shall refrain from any value judgment" and which cannot be used as a basis for dispute settlement. Already in this provision we can see the tension between multilateralism and regionalism and the reluctance of the WTO as an institution to take a firm stance for or against such RTAs. Another crucial contribution of this mechanism appears in paragraph 13, according to which:

All written material submitted, as well as the minutes of the meeting devoted to the consideration of a notified agreement will be promptly circulated in all WTO official languages and made available on the WTO website.

Additionally, paragraph 21 further discusses the electronic database to be established and maintained by the Secretariat, which "should be structured so as to be easily accessible to the public." Finally, Part E outlines the two committees entrusted with the implementation of the transparency mechanism, first the Committee on Regional Trade Agreements (CRTA) for RTAs and second the Committee on Trade and Development (CTD) for PTAs. Paragraph 19 authorizes the WTO Secretariat to provide technical support to developing and least-developed countries, another new feature introduced under the RTA/2006 Decision.

Besides the more lenient time-frames, the PTA/2010 Decision clarifies the role of the Secretariat and the CTD in the process of consideration of PTAs. An elaborate description of the contents of the factual presentation prepared by the WTO Secretariat is described in paragraph 9 of the PTA/2010 Decision:

[T] he Secretariat may also include in the factual presentation, as appropriate, the following elements: background information, scope and coverage (products and countries), exceptions, S\&D provisions, specific rules concerning the application of the scheme (graduation, eligibility for additional preferences), rules of origin, provisions affecting trade in goods (IP, labour, environment, TBT, SPS, trade remedies, if applicable), specific customs-related procedures, composition of merchandise imports from beneficiary member, fulfillment of TRQs, relationship with other PTAs by the same Notifying Member and imports under the PTA in the last three years, if applicable.

Similarly there is an electronic database of PTAs, on the WTO website which is available to the public. Figure 1 gives a summary of the consideration process flow chart established in both Decisions. ${ }^{49}$

$49 \quad$ Fiorentino et al., supra note 44, at 63. 


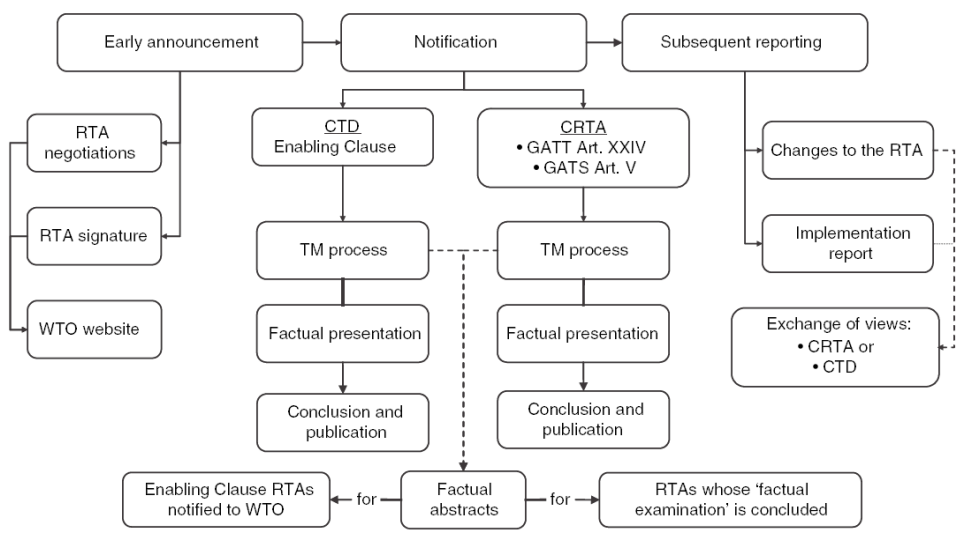

Figure 1: Processes established by the RTA/2006 and PTA/2010 Transparency Mechanism Decisions $^{50}$

These Decisions are a serious attempt to address the issues that Working Groups faced under the GATT when considering Customs Unions and Free Trade Areas. There have been very few cases in which such Working Groups have reached a conclusion on the compatibility of such agreements and the GATT. ${ }^{51}$ Transparency, namely disclosure, consideration and publication, is a significant first step in that direction. Still, neither decision, similarly to Articles GATT XXIV and GATS V provides for any consequences, should member states violate this process. As such, the enforcement record of both decisions is fragmented at best. ${ }^{52}$ The WTO website indeed has two portals, one for PTAs and one for RTAs. ${ }^{53}$ It appears however that not all RTAs and PTAs are notified there and overall, even the ones notified are not properly evaluated by the WTO. ${ }^{54}$ Another view is that the existing system has been overwhelmed by the legal definitions included in Articles XXIV GATT and V GATS, another issue impeding the RTA and PTA review process. ${ }^{55}$

Notably, an agreement was recently signed between Canada and the European Union, CETA, or the Canada-European Union Trade Agreement. ${ }^{56}$ Canadian Prime Minister Stephen Harper and EU President Jose Manuel Barroso discussed the

50 See Transparency Mechanism for RTAs, World Trade Organization, available at https://www.wto.org/english/tratop_e/region_e/trans_mecha_e.htm (last visited Jun. 10, 2016).

51 VAN Den Bossche, supra note 29 , at 709 \& n. 387.

52 Fiorentino et al., supra note 44, at 60.

53 Preferential Trade Agreements, available at http://ptadb.wto.org (last visited Jun. 10, 2016); Regional Trade Agreements, available at http://rtais.wto.org/UI/PublicMaintainRTAHome.aspx (last visited Jun. 10, 2016).

54 Matsushita et AL., supra note 16, at 554.

55 Gantz, supra note 20; Robert Gilpin, Global Political Economy: Understanding the INTERNATIONAL ECONOMIC ORDER 189 (2011).

56 EU and Canada Strike Free Trade Deal, EU Press release, Brussels Oct. 18, 2013, available at $\mathrm{http} / /$ trade.ec.europa.eu/doclib/press/index.cfm?id=973 (last visited Jun. 10, 2016). 
significance of the Agreement in a news conference, where Mr. Harper acknowledged that "This is a big deal. Indeed it is the biggest deal our country has ever made. This is a historic win for Canada." ${ }^{57}$ The translation and approval processes, in the EU member states' languages, and by provincial parliaments in Canada and as provided in the EU has been cited as the reason why the agreement had not been published for quite a long time. ${ }^{58}$ The Canadian government first published a summary of the agreement, which Trade Minister Ed Fast argued it provides "everything Canadians need to know" 59 and only later the full text. ${ }^{60}$ Even though the translation and notification procedures are reasonable in international relations, under the RTA/2006 Decision, the parties should already notify the WTO under the early announcement process or the bilateral trade agreement. Even though both Canada and the European Union are two of the strongest transparency proponents in the WTO, the two parties have failed to maintain a consistent attitude towards transparency, even after negotiations were concluded and the text was finalized. Essentially, the CETA example is indicative of the low enforcement capabilities of both General Council Decisions. More recently, there was another leak of the text of the agreement currently negotiated between the EU and the United States, TTIP, which produced more civil society backlash particularly in Europe on the lack of transparency in the negotiaitons' process. ${ }^{61}$

\section{AsymmetricAl ASPECTS OF PTAs/RTAs}

The multilateral trading system established by the GATT and the WTO does not prevent its members from concluding bilateral or multilateral trade agreements of a more limited scope (namely among only few WTO member states). Regional Trade Agreements used to be traditionally signed among countries in terrestrial proximity but currently the term in the WTO refers to reciprocal trade agreements between two or more partners. They include Free Trade Agreements and Customs Unions. Preferential Trade Agreements involve unilateral trade preferences. They

57 Paul Waldie, Canada, EU Unveil 'Historic' Free-Trade Agreement, The Globe And MaIL (Oct. 18 2013).

58 Id.

59 Stuart Trew, Is Canada Legally Bound to Release the CETA Text?, CounCIL-OF-CANADIANS's BLOG (Nov.8 2013) parts available at http://rabble.ca/blogs/bloggers/councilcanadians/2013/11/canada-legally-bound-to-release-ceta-text.

60 Canada-European Union: Comprehensive Economic and Trade Agreement (CETA), available at http://www.international.gc.ca/trade-agreements-accords-commerciaux/ agr-acc/ceta-aecg/index.aspx?lang=eng.

61 The text was leaked by Greenpeace and published in https://ttip-leaks.org (last visited Jun. 10, 2016). See also Sewel Chan, Greenpeace Leaks U.S.-E.U. Trade Deal Documents, N.Y. Times May 2, 2016; Peter Buxbaum, Leaked TTIP Documents Met With Furor in Europe, Silence in U.S.: EC Trade Commissioners Says Positions Outlined in Texts Will Not Make It to Final Accord, available at http://www.globaltrademag.com/ global-trade-daily/news/leaked-ttip-documents-met-with-furor-in-europe-silence-in-u-s (last visited Jun. 10, 2016); Trevor Timm, The TTIP and TPP Trade Deals: Enough of the Secrecy, The Guardian, May 42016. 
include Generalized System of Preferences schemes as well as other non-reciprocal preferential schemes granted a waiver by the General Council.

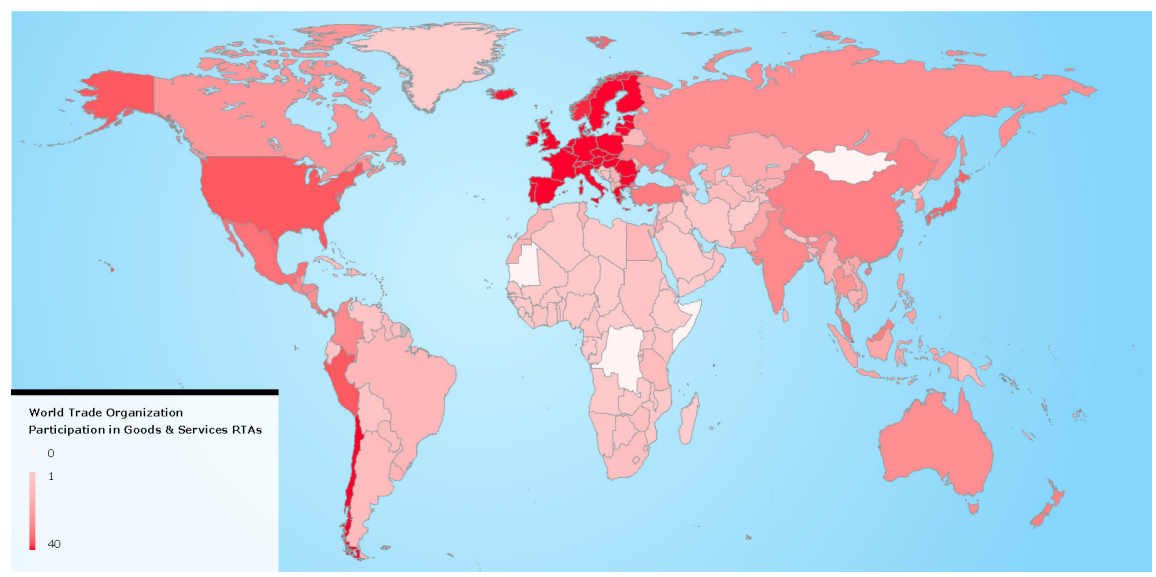

Figure 2: Map of RTA participants ${ }^{62}$

PTAs and RTAs are exceptions to the Most Favored Nation rule of Article I:1 of the GATT. In essence, both the GATT/WTO and PTAs/RTAs aim towards trade liberalization, albeit at a different scale, and while the WTO is based on the principle of non-discrimination, the same does not apply to PTAs/RTAs, which have a discriminatory logic in their rationale. ${ }^{63}$ The two schemes pursue the same goal using contradictory rules, creating some reasonable frustration with respect to their compatibility. ${ }^{64}$ The unexpressed rationale for such agreements is that more liberalization, even if it occurs at a bilateral level, is better than no liberalization at all. Moreover, the GATT Founding Members at the time most likely did not want to annul their regional trade relations agreements, so instead of dealing directly with a possibility of conflict between multilateralism and preferential access to certain markets, they included an exception. Thus, it is very likely that the same subject matter is covered by PTAs/RTAs and the WTO rules, creating the potential for conflict. ${ }^{65}$

This asymmetry is intensified due the large volume and the importance of regional agreements. ${ }^{66}$ We need to go no further than point to the European Union,

62 Participation in Regional Trade Agreements, available at https://www.wto.org/english/ tratop_e/region_e/rta_participation_map_e.htm (last visited Jun. 10, 2016).

63 Fiorentino, supra note 44, at 54-55.

64 Ironically an argument can be made that the WTO could aspire to be a global customs union or regional trade agreement, see as an analogy Murray Kemp \& Henry Wan, An Elementary Proposition Concerning the Formation of Customs Unions, 6 J. INT'L ECONOMICS 95, 96 (1976).

65 Thomas Cottier \& Marina Foltea, Constitutional Functions of the WTO and Regional Trade Agreements 43-76, at 53 (2006).

66 See Figure 3 for data on numbers of Regional Trade Agreements concluded between 1948 and 2014. 
the North American Free Trade Agreement (NAFTA), MERCOSUR and the Association of Southeast Asian Nations (ASEAN). These agreements have strong impact for the trade amongst their members and are only four of the hundreds of bilateral and multilateral agreements that essentially provide an exception to the cardinal GATT rule of non-discrimination. As such, concerns have been raised that such agreements undermine "the transparency and predictability of trade relations. ${ }^{~} 67$

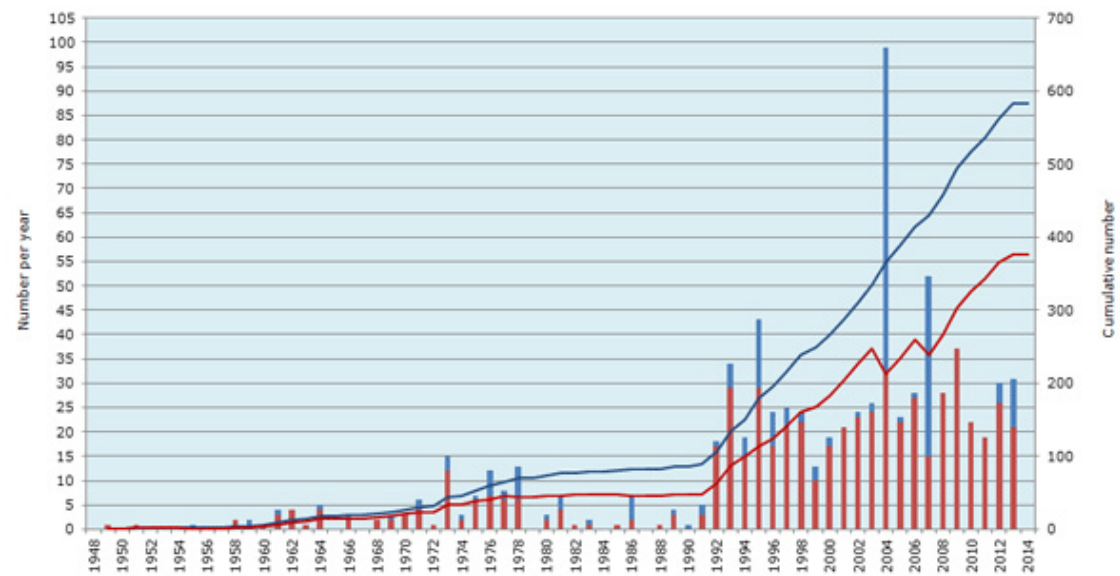

Figure 3: Regional Trade Agreements Concluded between 1948 and $2014^{68}$

Concerns with respect to the exclusionary nature of PTAs and RTAs are not unwarranted. A particular statement of U.S. Trade Representative Robert Zoellick in Cancun during the 2003 WTO Ministerial shows that advanced economies, when they cannot achieve the type of agreements they want in the multilateral trading system, resort to coalitions of the few. In Cancun, developing countries finally actively demanded that their needs be part of the agenda, or else they would not allow for the negotiations and the new Round to move any further. Instead of embracing these requests, even in the slightest, the U.S. Trade Representative retaliated with turning to a form of "coalitions of the willing." It is interesting to see how Paul Blustein reported Zoellick's reactions after the G-20's Cancun stand-off:

Reflecting his frustration over the events in Cancún was an op-ed he wrote in the Financial Times on September 22, 2003, a few days after the meeting. He blasted his adversaries - Brazil was mentioned five times - for having fostered a "culture of protest that defined victory in terms of political acts rather than economic results." He made it clear that he was going to reward cooperative

67 Fiorentino, supra note 44, at 28.

68 Regional Trade Agreements, Facts and Figures, available at https://www.wto.org/english/tratop_e/region_e/regfac_e.htm (last visited Jun. 10, 2016). 
countries and punish uncooperative ones by intensifying his "competitive liberalization" strategy of pursuing trade deals on multiple levels:

[Zoellick wrote]: "The key division at Cancún was between the can-do and the won't-do. For over two years, the U.S. has pushed to open markets globally, in our hemisphere, and with sub-regions or individual countries. As WTO members ponder the future, the U.S. will not wait. We will move towards free trade with can-do countries."

America's market of 300 million free-spending consumers, in other words, would be used as both a carrot and a stick. Countries that shared Washington's enthusiasm for freer trade would obtain preferential access to that market by signing bilateral and regional agreements eliminating most trade barriers between them and the United States. Meanwhile, the ranks of the reluctant would be left at a disadvantage; their products would be subject to the tariffs that Washington maintained on MFN terms for members of the WTO. Eventually, they would recognize that their self-interest lay in joining the U.S.-led bandwagon, the result being that small deals would prove to be "building blocks" toward bigger ones and, ultimately, a worldwide one. ${ }^{69}$

This passage highlights the exclusionary underpinnings behind the will of powerful countries to enter PTAs and RTAs. Arguably, there exist strong links between the statement by Bob Zoellick and the finalization of TTP, as well as the advanced stage that TTIP negotiations are at now. The difference of obtaining consensus in the realm of the WTO versus plurilaterally is significant; indeed the Green Room problems exclude smaller states from initial consultations, but eventually they are added in the negotiations and can meaningfully, alone or in coalitions, engage in discussions on legal and economic parameters of new WTO agreements. If the forum of negotiations is outside the WTO altogether, third parties can in no way be part to any of the process. ${ }^{70}$

\section{PTAs/RTAs AND TRADE LiBERALIZATION}

The debate on regional integration as an optimum versus the multilateral path as the best way to foster trade liberalization has yet to produce concrete and conclusive results. On one hand it can be argued that regional trade integration leads to faster trade liberalization, even if it occurs outside the WTO. Economic ties amongst smaller groups may be stronger, the costs of negotiations are lower since fewer parties are involved and elimination of tariffs inside the PTA or the RTA can occur much faster than in the multilateral framework. Coupled with this idea is that political reasons (not only economic) may lie behind deeper integration, as is the case for the (arguably unique in this respect) European Union. This argument favors PTAs and

69 Paul Blustein, Misadventures of the Most Favored Nations 174 (Public Affairs 2009) (emphasis added).

70 See also Nicholas Lamp, The Club Approach to Multilateral Trade Lawmaking (Queen's University Legal Research Paper No. 2015-005, 2014), available at SSRN: http://ssrn. com/abstract $=2574864$ (last visited Jun. 10, 2016). 
RTAs as they appear to be creating more trade. ${ }^{71}$ Another interesting phenomenon in the RTA proliferation has been the rise of "new players" in international trade, such as the trading bloc of South American countries, ${ }^{72}$ the Asian Tigers, ${ }^{73}$ Brazil, Russia, India, China and South Africa (BRICS) and Middle Income countries, fundamentally changing the landscape of international trade.

On the other hand, several studies on customs unions and free trade areas suggest that the trade-diversion effects may be greater than the trade-creation, especially since PTAs and RTAs favor trade amongst participants, resulting in less trade with members of the PTAs and non-members. ${ }^{74}$ Trade economists have in fact argued that regionalism leads to factionalization, and PTAs may be optimal to protectionism, but they will always fall to the second-best spot ${ }^{75}$ compared to a functioning global free trade system, since multilateralism in the WTO context entails a global vision lacking in regionalist integration models. ${ }^{76}$

Moreover, regional trading agreements cannot be fully open to accession from third parties. If they remained opened to membership, the original parties would have fewer incentives to commit to lowering trade tariffs for fear of considerable changes in value of their preferences with the accession of a new party. Such problems are not as prevalent in a multilateral context. For example, the accession of China, a huge country and a great trading partner, may have taken years to conclude but the commitment to trade liberalization always supports accession of new members instead of exclusion. The exclusionary potential is however prevalent in regionalism.

The intensified attention on PTAs and RTAs in the Doha Declaration reflects the current "regionalization" of international trade (or "new regionalism") ${ }^{77}$ which is portrayed as a group of systems which are "not attempting to shield themselves from the global economy and are rather trying to maximise their participation in it." ${ }^{78}$ However the inefficiency of existing transparency mechanisms as well as the utilization of Preferential Trade Agreements as a way out of negotiation difficulties at the multilateral level have rendered PTAs "stumbling blocks" for world trade for smaller economies which cannot negotiate such agreements as equals and rely on the GATT MFN for access to other countries' trade markets. ${ }^{79}$

With respect to transparency and monitoring, despite the existence of substantial mechanisms, in addition to Article XXIV and the Understanding on Article XXIV, Article V of the GATS and the Generalized System of Preferences,

Fiorentino, supra note 44, at 695.

Which GANTZ, supra note 20, calls the Jaguars.

73 TreBilcock, supra note 9, at 197 discussing the rapid growth in intra Asian trade, and GANTZ, supra note 20.

74 Fiorentino, supra note 44, at 696.

75 Robert Lawrence, Regionalism, Multilateralism and Deeper Integration, 29-30 (1996).

76 TreBILCOCK, supra note 9, at 195.

77 For its characteristics see Chad Damro, The Political Economy of Regional Trade AgreEments 23-42, 27 (2006).

78 James Mathis, Regional Trade Agreements in the GATT/WTO 127 (2002). See more recently GANTZ, supra note 20 at 201.

79 Nordström Håkan, Participation of Developing Countries in the WTO - New Evidence Based on the 2003 Official Records, in WTO Law And Developing Countries 170 (George A. Bermann \& Petros C. Mavroidis eds., 2007). 
their enforcement momentum is low, at best. The web of RTAs and PTAs has grown very rapidly in the last decade. In contrast to the Doha Development Round, where all agreements must be considered under a single undertaking and also need to be agreed upon by consensus, regionalism has significantly expanded, to cover for the regulatory space of trade liberalization that multilateralism does not seem to achieve, albeit only for small groups, producing regulatory cooperation in trade matters that have not occurred at the WTO among all member states.

The WTO has committed institutionally to monitor, consider and publish the RTAs and PTAs. As it remains unclear whether in fact such regional initiatives undermine the multilateral agenda of the WTO, consideration beyond a superficial examination is rendered difficult. Similarly, not all agreements have been published as we saw previously, illustrated by CETA and TTIP. A possible solution for this problem is to introduce some form of a penalty system for failure to properly notify and publish such agreements in the WTO. Another more obvious solution is to raise the budget for the monitoring mechanisms, partially remove their member-driven elements and assign a new part of the WTO Secretariat specifically to monitoring duties. Rather than relying on Working Groups of member state committees to carry out the vast amount of monitoring, it might be preferable to rely on the administration instead. Working Groups can be introduced at a second stage, after the collection of sufficient economic data and the drafting of initial but extensive reports.

As RTAs and PTAs have multiplied over the years, they have been described as a "spaghetti bowl", or a "noodle bowl" or even a "lasagna dish." ${ }^{80}$ Pasta-metaphors aside, RTAs and PTAs create a very large web of agreements that can have negative effects on all those left outside of these cooperative structures and compromises general trust in the multilateral structure of trade negotiations. Keeping track of them alone consumes a part of the WTO resources. One proposal in order to remedy these detriments is to place a cap on the number of the Agreements. ${ }^{81}$ Introducing a straightforward cap on PTAs and RTAs may cause a sort of revolution in the WTO and never reach consensus. Thus one form of moratorium could be based either on trade volume covered, or a set of products that can be agreed on by all WTO members to remain outside the scope of PTAs and RTAs. If the United States and the European Union are serious about their commitment to multilateralism then such an agreement can give them an opportunity to show it. Additionally WTO members could discuss the possibility for compensatory mechanisms in case of Agreements, which are found to violate WTO rules.

Finally, we should note here that there is one set of PTAs that should not be scrutinized nor be altered as they would end up reducing development assistance or otherwise negatively affect developing and least-developed countries agreements giving preferential treatment to least-developed countries should be sustained, as they are key to their economies and trade ${ }^{82}$ or at least be converted to import

\footnotetext{
80 Jagdish Bhagwati, US Trade Policy: The Infatuation with FTAs, ACADEMIC COMmons (1995); Id., The Noodle Bowl,: Why Trade Agreements Are All the Rage in Asia, THE ECONOMIST , 3 Sept. 2009.

81 Paul Blustein, Misadventures of the Most Favored Nations 277 et seq. (Public Affairs 2009).

82 Håkan, supra note 79, at 170.
} 
subsidies that would benefit them equally. ${ }^{83}$ Moreover there is an additional positive spillover of PTAs for least-developed countries. During smaller scale negotiations smaller countries can refine their negotiating tactics. An interesting example is the case of Zambia and Mauritius as participants in the Common Market for Eastern and Southern Africa (COMESA) and the Southern African Development Community (SADC). The participation of the two countries in both Regional Trade Agreements has assisted them in preparations for negotiations in the WTO context by providing training, raising awareness, and overall giving a more familiar forum with countries facing similar issues for the exchange of trade information and ideas. ${ }^{84}$

The official rhetoric in the WTO context does not emphasize the exclusionary potential of such agreements at all. In the next section we will see how one of the most important self-assessment documents, the Sutherland Report, confronted with the issue of development and regionalism, did not engage in meaningfully pointing out any of the negative impact that such PTAs and RTAs may have, for either the international trading system as a whole or for its weaker members.

\section{The Sutherland Report on PTAs/RTAs and Development}

In view of the WTO $10^{\text {th }}$ anniversary in 2005 , the then Director-General Supachai Panitchpakdi commissioned a report from a consultative board consisting of the former Director-General of the WTO, Peter Sutherland and a few select members of governments, academics and policy-makers. The result was a report entitled "The Future of the WTO: Addressing Institutional Challenges in the New Millennium." ${ }^{85}$ Previously, in 1983, GATT Director-General Arthur Dunkel had similarly commissioned the "Leutwiler Report", which actively pushed towards the initiation of the Uruguay Round and the establishment of a robust multilateral trading system. The Sutherland report looks at the functioning of the WTO as an institution.

The report purports to be an evaluation of the WTO and to discuss legitimacy concerns concerning the WTO. In its nine chapters, the report discusses central issues such as the relationship between the WTO and Globalization and Sovereignty (Chapters I and III), the erosion of non-discrimination mostly due to national protectionism and Regional and Preferential Trade Agreements (Chapter II), the problems of the consensus voting rule, political reinforcement, process efficiency and the WTO's variable geometry (Chapters VII and VIII), the relationship of the

83 Limāo Nuno \& Marcelo Olarreaga Trade Preferences to Small Developing Countries and the Welfare Costs of Lost Multilateral Liberalization, in WTO LAW AND DEVELOPING Countries 36-58 (George A. Bermann \& Petros C. Mavroidis eds., 2007).

84 Sanoussi Bilal \& Stefan Szepesi, How Regional Economic Communities Can Facilitate Participation in the WTO: The Experience of Mauritius and Zambia, in Managing the Challenges of WTO Participation: 45 Case Studies 389-90 (Peter Gallagher et al. eds., 2005).

85 The Future of the WTO: Addressing Institutional Challenges in the New Millennium, available at https://www.wto.org/english/thewto_e/10anniv_e/future_wto_e.pdf [hereinafter Sutherland Report]. 
WTO with other international organizations (Chapter IV), transparency and civil society participation (Chapter V), the dispute settlement system (Chapter VI) and challenges and improvements of administrative nature for the Secretariat and the Director General (Chapter IX).

Even though the report includes some (albeit very limited) constructive criticism for the WTO, it is largely an apologetic document, a defense of the WTO ${ }^{86}$ and those aspects of globalization that provide fertile ground for the economic paradigm under which the organization operates. It has been criticized as a "trade liberalization gospel"87 which is "trapped in [its] functionalist straightjacket." Its conclusions are seen as unconvincing ${ }^{88}$ as being an attempt to defend "the status quo by WTO insiders." ${ }^{89}$ Indeed, the members of Consultative Board are linked to the WTO; the report was written only by them, without the participation of civil society actors, and it even mentions that one goal of the report is to "revisi[ $t$ ] some of the fundamental principles of the trading system that, in our view, have been greatly misunderstood or misrepresented." ${ }^{90}$ Among the academics discussing the Sutherland Report, a small fraction who have or have had an institutional affiliation with the organization are the only ones who agree with the analysis and conclusions of the Report. ${ }^{91}$ The usefulness of the Sutherland Report does not lie in providing answers for the legitimacy problems of the WTO, as it seems to be giving the WTO a perfect score. However, it helps delineate some issues, and thus we can sketch a rough territory where the WTO needs improvements.

The report did not adequately address the central issue of development in the WTO, in the form of the negotiating asymmetries for developing countries as well as the incomplete and fragmented understanding of development needs, coupled with a blind trust on the trade liberalization paradigm. For as long as trade negotiations resulted in lower trade tariffs, the legitimacy issues facing the international trading system (the GATT at the time) remained less visible. Developing countries voiced their frustration on a number of occasions, but the institutional response, reflecting developed countries' convictions was that as long as developing countries stay on the trade train, they will eventually gain some speed, reduce poverty and create prosperity for themselves. Since 1995 and the Uruguay Round results, we have yet to witness a successful trade round. Legitimacy as a derivative of trade negotiations and their resulting tariff reductions is no longer a plausible narrative in WTO discourse. Thus, in the ten-year anniversary of the WTO, the Sutherland Report had the opportunity to reframe the issue of development in the WTO. In view of the Doha Development Round, the Report could take advantage of the opportunity and

86 Joost Pauwelyn, The Sutherland Report: A Missed Opportunity for Genuine Debate on Trade, Globalization and Reforming the WTO, 8 J. INT'L Econ. L. 329 (2005).

87 Deborah Z. Cass, The Sutherland Report: The WTO and Its Critics, 2 INT'L ORG. L. Rev. 153,154 (2005).

88 Armin Von Bogdandy \& Markus Wagner, The Development of the WTO-Remarks on the Sutherland Report, 2 InT'L ORG. L. Rev. 167, 168 (2005).

89 Pauwelyn, supra note 86, at 329. See also on page 7 of the Sutherland Report, supra note 85 , the short bios of the Consultative Board, all of whom have long-standing careers in international organizations.

90 Sutherland Report, supra note 85 , at 5.

${ }_{91}$ For example, see William J. Davey, The Sutherland Report on Dispute Settlement: A Comment. 8 J. InT'L Econ. L. 321 (2005); Mitsuo Matsushita, The Sutherland Report and Its Discussion of Dispute Settlement Reforms, 8 J. InT'L Econ. L. 623 (2005). 
revisit the liberalization paradigm. Instead, citing a number of "empirical studies" and in sync with the Report's tone, development and internal transparency concerns are barely addressed. It is their own "autarkic, inward-looking policies" and "their own protection" that "undermined the developing countries' export performance by creating a "bias against exports." " 92 Countries which benefit from preferential rules become "over-reliant on preference." 93

The "it's-not-us-it's-you" tone of the report continues during the second theme, which dominated the criticism of the report. The openness of the organization towards civil society and NGOs is deemed satisfactory; the Secretariat does not have sufficient resources to do more; and, some of these organizations are intransparent themselves in the way they operate on a day-to-day basis. This type of reasoning was greatly criticized, and rightfully so, in the literature. Such a line of argumentation, not only fails to address but indeed fuels legitimacy problems, carries little normative value and does not contribute to a good governance model.

The Report falls short of explicitly and systematically discussing larger institutional problems and power asymmetries in the WTO, as well as the balance between legitimate national concerns for regulation and the principle of nondiscrimination. State sovereignty has been eroded through participation in the WTO. The WTO has a long reach and affects a large segment of the domestic legal orders of its members, because of the pervasive nature of trade. Additional Agreements, especially the Agreement on Trade Related Aspects of Intellectual Property Rights (TRIPS), Technical Barriers to Trade (TBT) and GATS can leave economists hard-pressed to think of areas where the WTO has no relevance. The Sutherland Report adopts an analysis that treats the WTO as one of many intergovernmental organizations and the reduction of state sovereignty as a product of the proliferation of organizations. This obscures the fact that trade regulation is highly intrusive on national legislations and since the Uruguay Round the WTO has extended its reach in a vast area of jurisdiction. As such, national parliaments are de facto sidestepped. Any legitimacy discussion surely does not need to propose the demise of the current trading system, intrusive as that system may be or seem. Instead, the Report could have pointed out avenues for the re-politicization of interest areas in order to reintroduce debates and participation of stakeholders that would have been part of national deliberation processes had the WTO not acquired jurisdiction in these areas. Both for underestimating the deflation of sovereignty, and for failing to remedy the legitimacy issues that deflation causes, the report falls critically short.

Chapter V of the Report contains some discussion on internal transparency, that is, negotiating asymmetries among WTO member states, especially present in the tension between developed and developing countries. ${ }^{94}$ Internal transparency ironically is discussed in the context of justifying the need for secrecy of negotiations. Interestingly, despite the Doha Development Round and its challenges, and its explicit mention in Paragraph 10 of the Doha Declaration, the report does not elaborate on how internal transparency is compromised in the WTO by the treatment of developing countries. ${ }^{95}$

\footnotetext{
Sutherland Report, supra note 85, para. 92.

Id. para. 101 .

94 Robert Wolfe, Decision-Making and Transparency in the 'Medieval' WTO: Does the Sutherland Report Have the Right Prescription?, 8 J. InT'L Econ. L. 631, 639 (2005).

95 Pauwelyn, supra note 86, at 336-37.
} 
Paragraph 222 of the report interestingly notes that developing countries participate much more in the Dispute Settlement Process than in the GATT, and "developing countries - even some of the poorest (when given the legal assistance now available to them) - are increasingly taking on the most powerful. That is how it should be." This statement is largely exaggerated. In fact, there still exist WTO member states that have never participated in the dispute settlement system, not even as third parties. Isolated examples like that of Antigua and Barbuda show that perhaps the system works, but it works for those who use it, which is not the overwhelming majority of the WTO. Also despite its victory against the United States during dispute settlement, the subsequent effective inability to implement the report should warrant a revision of the implementation rules. When crossretaliation is allowed only within the domestic market of the winner, and the winner is a micro-state, then cross-retaliation is meaningless; no sector can be large enough to harm the strong state that stood on the other side of litigation. That is not "how it should be."

Once again in the report, the opportunity is missed to discuss at a pragmatic level how to bring developing countries not up to speed with trade, but on equal footing with their counterparts at an institutional level. ${ }^{96}$ The repeated failures to conclude a negotiating round in Doha and later in Bali demonstrate that the institutional and collective reluctance to tackle internal transparency as a serious issue comes at a high cost that threatens the WTO's main function. This institutional reluctance is evident in the Sutherland Report. The Green Room issue is barely addressed. Emphasis is instead placed on the need for confidentiality of negotiations, a discussion on variable geometry and a gospel for the current negotiation arrangements that perpetuate the internal transparency deficits and are, in relative terms, archaic, since they are reminiscent of the GATT days.

Some discussion on least-developed countries appears later in the report ${ }^{97}$ but does not explore their real problems with the WTO. They are mentioned as "unfortunately, insignificant in terms of world trade (even collectively)." However, as it appears from the Doha Round, collectively they can contribute to blocking further decision-making and their accession process takes a very long time (despite their "insignificance") as we will see in the next section on accessions and internal transparency lato sensu.

It is important to note here that even though the Sutherland Report rightly observes that the institutional and monetary resources of the WTO are not unlimited, this does not mean that focus on one form of transparency necessarily needs to occur at the expense of the other. ${ }^{98}$ This perspective fails to capture the fact that institutional and pecuniary constraints reflect a lack of support from member states, another issue that should be remedied. Also, considering the extent of the WTO's legitimacy crisis, addressing these legitimacy problems should be a first priority for the organization, both at the internal and at the external level.

\footnotetext{
96 Dan Sarooshi, The Future of the WTO and Its Dispute Settlement System, 2 InT'L Org. L. REv. 129, 151 (2005).

97 Sutherland Report, supra note 85, at 67 et seq., para. 306 et seq.

98 Donald McRae, Developing Countries and 'The Future of the WTO', 8 J. INT'L Econ. L. 603 (2005).
} 
The Report discusses Preferential Trade Agreements and regionalism. ${ }^{99}$ Although it mentions that the vast majority of the PTAs and RTAs have not been notified and all but one have never been examined for compatibility with the WTO Agreements, the Report does not encourage the organization to expose this state of affairs. ${ }^{100}$ It engages in a discussion on whether such agreements promote or undermine the world trading system, only to conclude that the evidence and research is inconclusive. The systemic reluctance to discuss Regional Trade Agreements remains. We can hypothesize that this occurs at the expense of the less powerful players in the WTO. ${ }^{101}$ Insofar PTAs are not even notified with the WTO, and power asymmetries are caused and perpetuated by PTAs the transparency deficit in this respect is massive, and it results both from the lack of disclosure and marginalization of member states.

\title{
VII. EXPANDING THE NOTION OF INTERNAL TRANSPARENCY
}

Internal transparency in the WTO is defined as "the issue of effective participation of developing countries in WTO decision-making." 102 In 2001, internal transparency was included as an issue in Paragraph 10 of the Doha Ministerial Declaration as follows:

\begin{abstract}
Recognizing the challenges posed by an expanding WTO membership, we confirm our collective responsibility to ensure internal transparency and the effective participation of all Members. While emphasizing the intergovernmental character of the organization, we are committed to making the WTO's operations more transparent, including through more effective prompt dissemination of information, and to improve dialogue with the public. We shall therefore at the national and multilateral levels continue to promote a better public understanding of the WTO and to communicate the benefits of a liberal rules-based multilateral trading system. ${ }^{103}$
\end{abstract}

Paragraph 10 of the Doha Declaration addresses both internal and external transparency, namely the relations between the WTO and citizens and civil society at large, although it only mentions the former by name. Arguably, Paragraph 10 could be divided in two to discuss internal transparency until the first period, and external for the rest of the paragraph. However, certain elements in the part after the first period can be seen as qualifiers for internal transparency: the WTO's intergovernmental character refers not only to the membership to the WTO and the conference of rights and duties reserved exclusively for states and not for other nonstate entities, but also, can be a reference to sovereign equality as the foundation

\footnotetext{
Sutherland Report, supra note 85, para. 68; paras. 75-87.

100 Pieter Jan Kuijper, Do Parallels with Other International Organizations Help, 2 INT'L ORG. L. REV. 191, 194 (2005).

101 Id.

102 VAN DEN Bossche, supra note 29, at 150.

103 Doha Declaration, supra note 5 (emphasis added).
} 
of international treaty-making competence. Sovereign equality is alluded to as it is possibly seen as a counterbalance, a cardinal notion in the foundation of international law that aspires to offset the problematic notion that some countries are not participating as effectively as others, as the first sentence implies. Even if internal transparency were formally recognized in the Doha Declaration, immediately after this recognition was tampered by an indirect reference to sovereign equality, significantly downplaying its importance.

The last sentence of paragraph 10 makes the notion of internal transparency even murkier. Issues of transparency are directly linked to lack of public understanding, without it being further clarified whether developing countries and their constituents are also victims to such a "misunderstanding" or this is a reference only to external transparency relating specifically to non-state stakeholders, citizens, consumers and for profit and non-profit entities. Finally, the last sentence, perhaps the most problematic of the entire paragraph is the one directional notion that only benefits are to be reaped from the liberal rules-based system that is the WTO. Even more here lie the notions that first, the problem with the WTO is not the lack of benefits, or that such benefits come from its liberal rules-based nature, but that all the above have somehow been lost in translation and not been communicated properly to those who are interested or care, or are affected by these rules; and second, that the very nature of the WTO as a legal system is decided and set, and what needs and can be negotiated is the communication of the benefits. This reduces Paragraph 10 to a debate on the WTO's public relations' agenda, and obscures the real issues that exist within the organization and that have resulted to a negotiations' standstill.

Since the Doha negotiation's deadlock, it is evident that internal transparency problems entail a lot more than an anomaly in the WTO's communications' strategies. This conclusion is also evident through literature that discusses law and development in the WTO; the lack of effective participation of developing countries is due to more embedded issues that date before the creation of the WTO, and even before the conclusion of the GATT, and are not unique to the international trading context. ${ }^{104}$ Moreover, when one explores exclusionary practices from some WTO member states against others in general, problems appear outside the development framework as well.

Thus, I argue that the definition of internal transparency should not be pegged to developing countries. Instead, it should be extended for three reasons. The first is the need to remain more faithful to the letter of the Doha Declaration. Paragraph 10 stipulates that internal transparency problems are linked to the expanding WTO membership, without an explicit mention of developing countries. Therefore, other participation hurdles caused by the increasing size of the organization should be considered under paragraph 10 .

Second, there are some similarities in the legal framework that addresses development in the WTO and two other sets of exceptions, namely regionalism and accession. A set of exceptions are set forth to address a different issue each time, putting in question the validity of cardinal rules in the WTO and whether they

104 See on the contextualization of development in public international law and WTO law Maria Panezi, Mapping the Territory: Contextual Jurisprudence, Legal Pluralism and WTO Law and Development: A Response to William Twining's Internal Critique Thesis from the Point of Transnational Jurisprudence, 4 Transnational Legal Theory 574-606 (2013). 
function as intended. In other words, it is paradoxical why such sets of exceptions are necessary to rules that represent the liberal rules-based trading system, which provides its members with benefits only. Third, the contextual parameters of the three sets of two-tiered processes exhibit similarities. There exist most importantly obvious stronger-versus-weaker state (or groups of states) dynamics, which further influence the processes followed to conclude these rules, their content and their monitoring mechanisms (when those are in place).

For these reasons I argue that internal transparency should extend to the exclusionary properties of Preferential and Regional Trade Agreements. Or, one could argue that developing countries' participation problems are issues of internal transparency stricto sensu while PTAs/RTAs belong to internal transparency lato sensu. Extending the definition of internal transparency to non-development related exclusionary problems can help us better understand the issue of non-effective participation to the world trading system, and can also help address fairness questions that do not exclusively appear in the development context.

A WTO member state can be facing exactly the same issues of complete disregard for its economic needs and inability to do much about it in the WTO context because of being left out from Preferential Trade Agreements. The agreement signed between the European Union and Canada (CETA), the MegaRegional signed among Australia, Brunei, Canada, Chile, Japan, Malaysia, Mexico, New Zealand, Peru, Singapore, United States and Vietnam (TPP) and the one that is currently being negotiated between the European Union and the United States (TTIP) can easily exacerbate the problems from extant subsidization practices from all three parties for their products at the expense of small economies. Canada, the European Union and the United States already dominate the world trading system. New agreements between them without the obligation to extend the privileges agreed through Most Favored Nation to anyone else can block entire sectors of global markets from any chances for prosperity. Additionally, a significant amount of intransparency exists with respect to PTAs in the WTO.

\section{The Renewed NaIrobi Transparency Commitment}

The 10th WTO Ministerial Conference took place in December 2015 in Nairobi, and it resulted in the signing of the Nairobi Ministerial Declaration. In the Declaration, WTO member states acknowledge the very little progress achieved on the Doha Development Agenda. However, for the first time since 2001, the Doha Round has been effectively marginalized in the negotiations, and it may only be a matter of time before it is declared unsuccessful and closed. ${ }^{105}$ This is conceded in Paragraph 30 of the Declaration, which contains a clear mention of the divide that the Doha Development Agenda has brought about and the desire for new approaches necessary in the WTO negotiations.

105 See for example the speech by Cecilia Malmström, Commissioner for Trade, "The WTO after Nairobi - Your Views on the Way Ahead", Civil Society Dialogue meeting of April 26, 2016, available at $\mathrm{http} / / /$ trade.ec.europa.eu/doclib/docs/2016/april/tradoc_154474.pdf. 
The Nairobi Declaration also addresses the issue of Regional Trade Agreements and their relationship to the WTO. In Paragraph 28 the Declaration mentions that:

\begin{abstract}
We reaffirm the need to ensure that Regional Trade Agreements (RTAs) remain complementary to, not a substitute for, the multilateral trading system. In this regard, we instruct the Committee on Regional Trade Agreements (CRTA) to discuss the systemic implications of RTAs for the multilateral trading system and their relationship with WTO rules. With a view to enhancing transparency in, and understanding of, RTAs and their effects, we agree to work towards the transformation of the current provisional Transparency Mechanism into a permanent mechanism in accordance with the General Council Decision of 14 December 2006, without prejudice to questions related to notification requirements.
\end{abstract}

There are two crucial observations made in this paragraph: first, the note that RTAs cannot be a substitute for the WTO and the multilateral trading system. Second, WTO member states recognize the need to take further action with respect to the proliferation of RTAs, and they link this to the transparency mechanisms we discussed in the previous section. We will look at each of the two observations in turn.

The large web of RTAs and the recent conclusion of Mega-Regionals, such as TPP and CETA indicate that the proliferation of a parallel system of trade obligations outside and beyond the WTO has not only considerable breadth, in terms of the number of countries participating, but also depth. The pervasiveness of RTAs is becoming progressively more obvious, as very large economies join these agreements. This increases the effects of marginalization of countries left out of the agreements which may want to join lest their trade interests are de facto negatively affected by being excluded. In some cases (like the TPP) there are provisions for joining in later, which mitigate these exclusionary properties to a certain extent. But that is not always the case, especially when two large trading partners (like the United States and the European Union, or the European Union and Canada) enter comprehensive "trade and ..." partnerships which can inflate the already large trading volume between the two parties. An understandable effect in the future could be that of negotiations of more RTAs among the smaller states which are affected by such FTAs.

Whether these agreements "complement" the WTO system as the Nairobi Declaration purports to do, is yet to be seen. In many cases the jurisdictional reach of the WTO and the FTAs do not overlap. In other words, the areas covered by the FTAs are not at all discussed in the WTO context. In that sense, indeed FTAs would be complementary. However, to reach this conclusion the multilateral system and the spaghetti bowl have to be compared side-by-side through both an economic and a legal lens. Such scrutiny is not done through any official mechanisms at the WTO level, nor at any perhipheral organizations.

This brings me to the second element of Paragraph 28, namely Transparency and Free Trade Agreements. The Nairobi Declaration reiterates the need for a coherent link between monitoring and the expansion of regionalism in the WTO. This has been recognized several times before, and the realization of the deficit resulted in the mechanisms we discussed in the previous section. To reaffirm this commitment, however, WTO member states took an additional step, and established the permanence of the previously provisional mechanisms. A very large number 
of RTAs remain without notification in the $\mathrm{WTO}^{106}$ - and by consequence without any scrutiny. As transparency is gaining significant space in the WTO regulatory framework, the extension and consolidation of monitoring processes are very important steps in the right direction with respect to RTAs. Additional steps need to be taken in order to support these mechanisms with the provision of sufficient resources, funds and personnel in order to better perform the tasks. WTO member states cooperation is necessary too. Members need to report in a timely manner the agreements they enter into. This helps with another aspect of RTA transparency, the disclosure of the agreements to the public earlier and in a fuller form. Latterly, a number of leaks have shown that there is desire for these agreements not only to be scrutinized on a peer-to-peer basis in the WTO, but also by civil society actors.

Finally, the WTO member states should engage further in discussing the type of examination they expect for RTAs from the monitoring mechanisms. There are three more specific problematic areas: first, a number of agreements have not been notified; second, existing (notified) agreements have not been extensively examined on their compatibility with the WTO Agreements; and third, there still exists no absolute clarity on the exact legal consequences where there is a mismatch between the WTO Agreements and an incompatible RTA. Perhaps the WTO system defers this discussion to the Dispute Settlement process. It would be beneficial if this discussion were formally introduced in the WTO, as it would further demonstrate that WTO member states are committed to promoting (and ensuring) the complementarity between RTAs and WTO Agreements.

\section{Mutual transPaRENCY SPILLOVERS: THREE PROPOSALS IN LIEU OF A CONCLUSION}

The landscape I described above alludes to fundamental changes in the world trading system. The WTO has extended numerous efforts to remain relevant in this context, and somehow manage the growing number of trade agreements outside its auspices. I will attempt in this last part, instead of a conclusion, to offer three proposals for the future of the relationship between the WTO and the spaghetti/ noodle bowl of PTAs/RTAs.

First, it appears that the tide of PTAs/RTAs that are being signed is very strong - too strong not to be taken very seriously in the WTO. The organization needs to be extremely sensitive to the changing nature of the world trading system. Making the transparency mechanisms permanent is a step in the right direction. Such initiatives need to multiply and acquire a more extensive mandate - the WTO needs more resources and formal mechanisms of assessment for PTAs and RTAs that are active and permanent. Beyond the substantive contribution of monitoring mechanisms in the WTO, the emphasis on transparency signals to the world trading system that the WTO is closely scrutinizing the complex web of these agreements

106 Members renew attempts to deepen WTO scrutiny of regional trade agreements, available at https://www.wto.org/english/news_e/news16_e/rta_08apr16_e.htm (last visited Jun. 10, 2016) and Committee on Regional Trade Agreements Submission from the United States, WT/REG/W/103. 
as they potentially have systemic implications for the covered Agreements. PTAs and RTAs result in closer economic integration and further trade liberalization but cannot replace the world trading system. The WTO by not only acknowledging but becoming a progressively active "third party" in the process (through constant monitoring) can help ease the asymmetries that the spaghetti bowl produces.

Second, the two forms of transparency discussed in this article, internal (persistence of power asymmetries) and legal (formal monitoring mechanisms) are complementary. If developing countries get proper assistance in the WTO, both through better rules and technical assistance, their negotiating position will improve, and as such, they will be able to negotiate PTAs and RTAs in terms that are better for themselves. ${ }^{107}$ Developing and least-developed countries can gain a lot from actively participating in monitoring of others' PTAs and RTAs in transparency and review mechanisms. This might prompt them to sign regional trade agreements with their key exporters and importers. Their more integrated participation in the world trading system, even in the form of regional agreements can help increase their trade volume and promote liberalization of crucial sectors, mitigate some of the international fora participation concerns and hurdles (as negotiators will gain experience in more limited settings and can transfer that know-how before the WTO). This will be most valuable for least-developed countries and countries with very low GDP which in the WTO are represented jointly by larger developing economies. The relationship between the two transparencies is interwoven but there still needs to be a conscious, continuous and specific effort on behalf of the WTO to link the two forms of transparency.

Third, some measures need to be taken initially in order to further clarify rules on PTAs/RTAs and mitigate the negative effects of Mega-Regionals on smaller countries. Not doing anything and letting various agreements play out until problems arise is not a proper response, multilateralism may be seriously compromised without any formal checks. One proposal could be to place some form of moratorium, a cap on further PTAs and RTAs until the remaining ones have been properly notified and an additional mechanism is put in place to ensure the compatibility of the obligations they create between their signatories with WTO rules. ${ }^{108}$ The WTO can also offer to "plurilateralize" smaller agreements, if members would like to open up participation in them. This may prove more difficult as members to smaller agreements would not want to dilute their rights and the exclusivity gained from participation.

Another idea, instead of a moratorium, would be to attach legal consequences to the failure to notify an agreement, or some privileges for notifying them properly. For example, if an agreement has not been notified, then it cannot be taken into account by the Panels and the Appellate Body on a potential dispute between two WTO members. This would add an additional layer to the analysis of the PeruGuatemala case; ${ }^{109}$ a Free Trade Agreement would need to not only be in force

\footnotetext{
Bilal \& Szepesi, supra note 84 , at 389-90.

108 Blustein, supra note 81 , at 277 et seq.

109 See conclusions, Appellate Body Report, Peru - Additional Duty on Imports of Certain Agricultural Products, WT/DS457/AB/R, WT/DS457/AB/R/Add.1 (July 20, 2015) and qT 7.25 et seq., Panel Report, Peru - Additional Duty on Imports of Certain Agricultural Products, WT/DS457/R, WT/DS457/AB/R/Add.1 (Nov. 27, 2014) (adopted Jul. 31, 2015 as modified by Appellate Body Report, Peru - Additional Duty on Imports of Certain Agricultural Products, WT/DS457/AB/R (July 20, 2015)).
} 
but also notified before the WTO in order for the court to consider it. This would give an incentive to WTO members to notify agreements, as usually the Dispute Settlement System is preferred to most other systems of settlement of disputes. If this were to be adopted, it should be seen as a lex specialis provision, not a contra legem approach to the Vienna Convention on the Law of Treaties. The Dispute Settlement Body has an unprecedented hybrid legal/political nature, with proper adjudicatory procedures (including a permanent appeals tribunal) and a political branch at the end of the process, and FTA members may very likely prefer their disputes adjudicated here. To require a notification of the FTA prior to adjudication does not seem like a burdensome requirement if parties want this agreement potentially taken into account when discussing their WTO rights and obligations.

The WTO remains the most important international trade forum. It is crucial to reinforce the multilateral platform that has been successful for so many decades, since 1947. Yet, adaptability to the changing landscape of world trade is equally essential for the organization. A more assertive stance that acts upon improving the two transparency forms discussed above will assist both the WTO and its member states support multilateral solutions over regional and more limited ones. A combined approach, in the spirit of the unique collaboration of William Shakespeare and John Fletcher may very well produce two noble kinsmen that can help the WTO improve its legitimacy profile. 